\title{
Fleet Management Simulation Using Queuing Theory to Achieve Coal Production Targets
}

\author{
Fahrul Indrajaya ${ }^{1}$, Yulian Taruna ${ }^{2}$, Johan Pranata Barus ${ }^{3}$, Yossa Yonathan Hutajulu ${ }^{4}$, Neny Fidayanti ${ }^{5}$, \\ A. A Inung Arie Adnyano ${ }^{6}$ \\ ${ }^{1}$ Faculty of Engineering, Universitas Palangka Raya, Palangka Raya, Indonesia, fahrulindrajaya@mining.upr.ac.id \\ ${ }^{2}$ Faculty of Engineering, Universitas Palangka Raya, Palangka Raya, Indonesia, yulian_taruna@mining.upr.ac.id \\ ${ }^{3}$ Faculty of Engineering, Universitas Palangka Raya, Palangka Raya, Indonesia, pjohan67@gmail.com \\ ${ }^{4}$ Faculty of Engineering, Universitas Palangka Raya, Palangka Raya, Indonesia, yossayonathan@ mining.upr.ac.id \\ ${ }^{5}$ Faculty of Engineering, Universitas Palangka Raya, Palangka Raya, Indonesia, nenyfidayanti@mining.upr.ac.id \\ ${ }^{6}$ Faculty of Mineral Technology, Institut Teknologi Nasional Yogyakarta, Yogyakarta, Indonesia, inungarie@itny.ac.id
}

\begin{abstract}
In the match factor, mining activity between the haulers and loader equipment dramatically affects each fleet's production. The purpose of this study is to simulate the sufficient number of transportation uses as an effort to achieve production targets using queuing theory. The research methods are quantitative and descriptive by analyzing the compatibility value of fleet, fleet production capability, queue number, and queue time. The data required is the time of the distribution, the distance from the mining front to the ROM, and the company's speed limit. The results of this research are beneficial to users of the transporter simulation to be applied based on the theory of the queue is six transport units in the Anggrek pit with a compatibility value of 1.01, five transport units in the Dahlia pit with compatibility value 0.98 , and five units of transport in the pit Anggrek with compatibility value 1.04. The haulers' recommendations were made by allocating two haulers units from the pit Anggrek to the Pit Dahlia and Kenanga. Each simulation's production capability reached the monthly production target, namely fleet Anggrek of $50,416.45$ tons, fleet Dahlia of 32,424.3 tons, and fleet Kenanga of 46,027.8 tons. Based on the study results, the achievement of production targets can be fulfilled by simulating the number of haulers usage and controlling fleet management's compatibility level on each working front.
\end{abstract}

Key words: Coal production, Fleet management, Match factor, Queuing theory, Simulation.

\section{INTRODUCTION}

The mining industry has a long-term interest in determining the efficiency and productivity of the use of production equipment [1]. Production equipment is often used in fleet management, namely transport and loading equipment [2]. Coal mining activities are used by various mechanical equipment, including excavators as loading tools, dump trucks as transportation means, and bulldozers as peeling equipment [3]. The coal mining project in the Kananai Block area in South Barito Regency, especially surface mining, is a capital-intensive business. Open-pit operational costs require about $50 \%$ to be allocated for hauling and loading equipment [4]-[6].

The match factor is a key performance indicator in mining equipment such as trucks and loaders [7]. In mining activities, the match factor between haulage and loading equipment greatly influences each fleet's production so that it is optimal [8], [9]. The current mining process is focused on managing the fleet, which always causes problems in the internal transportation system [10]. Equipment performance can be improved by simulating a sufficient fleet usage to meet the expected production target using queuing theory [11]. Based on the mining plan in the Kananai Block in November 2019, which consists of three pits, namely Anggrek pit, Dahlia pit, and Kenanga pit, which applies one fleet to each pit. Kananai Block coal mining activity use the open-pit method with loading equipment in the form of a backhoe and a Scania type dump-truck. Any mining activity is very important in optimizing fleet management to achieve coal production targets [12]. Management of the transport fleet in coal mining is a concept that combines fleet configuration, fleet allocation, and vehicle routes by considering vehicles that are homogeneous or heterogeneous [13]. The Kananai Block mining has a production target of 132,500 tons of coal with details of 50,200 tons of coal for the Anggrek pit target, 30,000 tons of coal for the Dahlia pit target, and 52,300 tons of coal for the Kenanga pit target.

Coal mining in the Kananai Block is still not optimal. It is because the standby time is too high due to the number of loaders that do not match the number of haulers on one front of the work, queues occur due to trucks overcapacity and fleet management that is not in accordance with field problems resulting in the production target not being achieved [14], [15]. The queuing theory for the three fleets in the Kananai Block can determine the Number of queuing points and the Number of main equipment requirements for mining activities [16]. This research is very important in 
Fahrul Indrajaya et al., International Journal of Emerging Trends in Engineering Research, 8(10), October 2020, 7099 - 7104

predicting the queue point, the number of haulers queuing in the system, the length of time waiting in line for the haulers, and the level of loaders activity according to the use of haulers in each mining fleet. Knowing the queue point can be overcome by allocating haulers so that queues can be minimized so that the system's use is effective.

Based on the actual condition of the field, it is necessary to analyze the needs of the tool based on the concept of Queuing Theory [17] to minimize the probability of lost time as well as create a simulation of fleet management in realtime [11], [18]. Applying the recommended number of tools based on queuing theory will maximize each fleet [19] and meet the monthly production target in the Kananai Block.

\section{RESEARCH METHODS}

The research methods were quantitative and descriptive by analyzing the compatibility value of fleet, fleet production capability, queue number, and queue time. The data collection consists of loading time, transportation time, dumping time, and time to return to the mining front on transportation. While the data needed on the backhoe excavator is digging time, swing load time, dumping time, and empty swing time. The data collected is then processed according to the flow chart (Figure 1). This research was conducted in the Anggrek, Dahlia, and Kenanga pits in the Kananai Block, South Barito Regency.

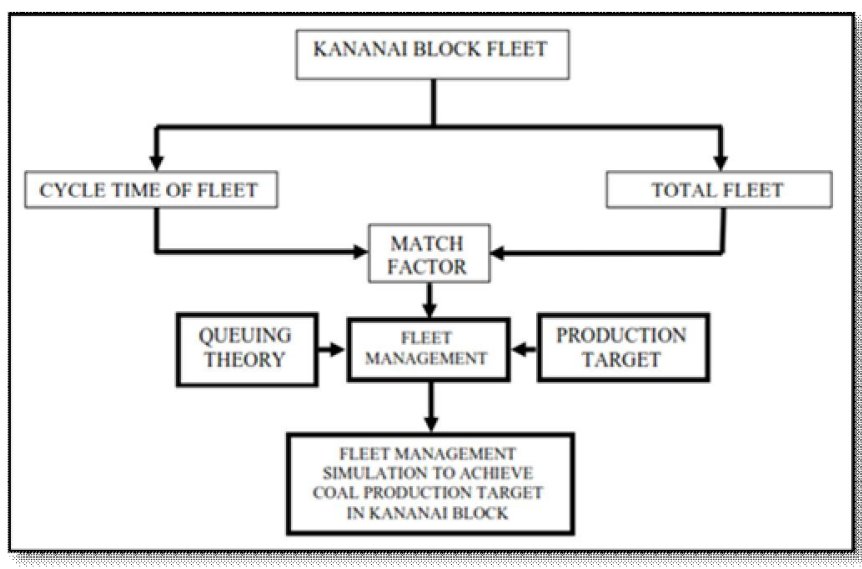

Figure 1: Research flow chart

According to the suitability theory of tools, there are three indicators, namely; $\mathrm{MF}<1, \mathrm{MF}=1$, and $\mathrm{MF}>1$. It aims to determine the fleet management simulation [20], [21]. Fleet management is carried out to optimize the condition of a fleet with a compatibility level of less than one (MF <1) and reduce overload truck conditions (MF>1).

After obtaining the value of the match factor for each wellorganized fleet [22], [23], the number of fleets used will be simulated based on queuing theory [17], [24]. The fleet management simulations offered are in the form of fleet numbers, designs, and mathematical concepts based on problems that often occur in actual conditions, such as efforts to achieve production targets by carrying out fleet mutations [25], [26]. The use of haulers on each mining front is obtained based on the probability of the situation using the following equation:

$$
\frac{(\mathrm{N}+\mathrm{M}-1) !}{(\mathrm{M}-1)(\mathrm{N}) !}
$$

$\mathrm{M}=$ Number of stages

$\mathrm{N}=$ Number of haulers

\section{RESULT AND DISCUSSION}

In the actual condition of the Blok Kananai fleet management, the Anggrek fleet was overstruck, causing queues. In contrast, the Dahlia and Kenanga fleets had a shortage of haulers, so that they did not reach the production target (Table 1).

Table 1. Current Fleet Management of the Kananai Block

\begin{tabular}{|c|c|c|c|c|c|}
\hline \multicolumn{2}{|c|}{ Anggrek Pit } & \multicolumn{2}{|c|}{ Dahlia Pit } & \multicolumn{2}{|c|}{ Kenanga Pit } \\
\hline \multicolumn{2}{|c|}{ Fleet Availability } & \multicolumn{2}{|c|}{ Fleet Availability } & \multicolumn{2}{|c|}{ Fleet Availability } \\
\hline Loader & Haulers & Loader & Haulers & Loader & Haulers \\
\hline \multirow{8}{*}{$\begin{array}{c}1 \text { Excavator } \\
\text { Unit ZX- } \\
350 \mathrm{H}-5 \mathrm{G} \\
\text { ID Number } \\
2063\end{array}$} & TC-3016 & \multirow{8}{*}{$\begin{array}{c}1 \text { Excavator } \\
\text { Unit PC- } \\
300 \text { ID } \\
\text { Number } \\
2057\end{array}$} & \multirow{2}{*}{ TC-3043 } & \multirow{8}{*}{$\begin{array}{c}1 \\
\text { Excavator } \\
\text { Unit ZX- } \\
\text { 350H-5G } \\
\text { ID Number } \\
2064\end{array}$} & \multirow{2}{*}{ TC-3070 } \\
\hline & TC-3019 & & & & \\
\hline & TC-3020 & & \multirow{2}{*}{ TC-3048 } & & \multirow{2}{*}{ TC-3094 } \\
\hline & TC-3021 & & & & \\
\hline & TC-3024 & & \multirow{2}{*}{ TC-3049 } & & \multirow{2}{*}{ TC-3104 } \\
\hline & TC-3030 & & & & \\
\hline & TC-3033 & & \multirow{2}{*}{ TC-3058 } & & \multirow{2}{*}{ TC-3105 } \\
\hline & TC-3034 & & & & \\
\hline
\end{tabular}

Based on the actual use of the Anggrek pits, Dahlia pits, and Kenanga pits, the compatibility values and production capabilities are obtained each month, as shown in Table 2.

Tabel 2. Match Factors Equipment Production Ability

\begin{tabular}{|c|c|c|c|c|c|}
\hline Fleet & $\begin{array}{c}\text { Number } \\
\text { of } \\
\text { loaders }\end{array}$ & $\begin{array}{c}\text { Number } \\
\text { of } \\
\text { haulers }\end{array}$ & $\begin{array}{c}\text { MF } \\
\text { Value }\end{array}$ & $\begin{array}{c}\text { Productions/ } \\
\text { Month }\end{array}$ & $\begin{array}{c}\text { Targets } \\
\text { Achievement }\end{array}$ \\
\hline Anggrek & 1 unit & 8 unit & 1,34 & $\begin{array}{c}67223.99 \\
\text { Tons }\end{array}$ & Achieved \\
\hline Dahlia & 1 unit & 4 unit & 0,79 & $\begin{array}{c}25939.4 \\
\text { Tons }\end{array}$ & $\begin{array}{c}\text { Not } \\
\text { Achieved }\end{array}$ \\
\hline Kenanga & 1 unit & 4 unit & 0,83 & $\begin{array}{c}36821.5 \\
\text { Tons }\end{array}$ & $\begin{array}{c}\text { Not } \\
\text { Achieved }\end{array}$ \\
\hline
\end{tabular}

Fleet management simulations are prepared based on the situation and availability of the fleet in the Kananai Block. The calculation results obtained from the Queuing Theory table for the three fleets in the Kananai Block in determining the Number of queuing points and the Number of main equipment requirements for mining will be discussed further.

\subsection{Determination of Service Level}

In determining the level of service in accordance with the rules of queuing theory, the components of the distribution time are divided into 4 stages, namely filling time, placement 
Fahrul Indrajaya et al., International Journal of Emerging Trends in Engineering Research, 8(10), October 2020, 7099 - 7104

time, hauling, dumping placement time, dumping, and hauling empty (Table 3).

Table 3. Determination of Unit Service Level

\begin{tabular}{|c|c|c|c|c|c|}
\hline Fleet & Indicators & Phase I & Phase II & Phase III & $\begin{array}{l}\text { Phase } \\
\text { IV }\end{array}$ \\
\hline \multirow{4}{*}{$\begin{array}{c}\text { Fleet } \\
\text { Anggrek }\end{array}$} & \multirow{2}{*}{$\begin{array}{l}\text { Activity } \\
\text { Details }\end{array}$} & $\begin{array}{c}\text { Time of } \\
\text { Placement }\end{array}$ & \multirow{2}{*}{ Hauling } & $\begin{array}{c}\text { Time of } \\
\text { Placement }\end{array}$ & \multirow{2}{*}{$\begin{array}{c}\text { Hauling } \\
\text { Empty }\end{array}$} \\
\hline & & $\begin{array}{c}\text { Charging } \\
\text { Time } \\
\end{array}$ & & $\begin{array}{c}\text { Dumping } \\
\text { Time } \\
\end{array}$ & \\
\hline & $\begin{array}{c}\text { Duration } \\
\text { Time }\end{array}$ & $\begin{array}{c}9.44 \\
\text { minutes / } \\
\text { truck }\end{array}$ & $\begin{array}{c}17.83 \\
\text { minutes / } \\
\text { truck }\end{array}$ & $\begin{array}{c}3.83 \\
\text { minutes / } \\
\text { truck }\end{array}$ & $\begin{array}{c}15.48 \\
\text { minutes } \\
/ \text { truck }\end{array}$ \\
\hline & $\begin{array}{c}\text { Probability } \\
\text { of Arrival }\end{array}$ & $\begin{array}{c}7 \text { trucks / } \\
\text { hour }\end{array}$ & $\begin{array}{c}4 \text { trucks / } \\
\text { hour }\end{array}$ & $\begin{array}{c}16 \text { trucks / } \\
\text { hour }\end{array}$ & $\begin{array}{c}4 \text { trucks } \\
/ \text { hour }\end{array}$ \\
\hline \multirow{4}{*}{$\begin{array}{l}\text { Fleet } \\
\text { Dahlia }\end{array}$} & \multirow{2}{*}{$\begin{array}{l}\text { Activity } \\
\text { Details }\end{array}$} & $\begin{array}{c}\text { Time of } \\
\text { Placement }\end{array}$ & \multirow{2}{*}{ Hauling } & $\begin{array}{c}\text { Time of } \\
\text { Placement }\end{array}$ & $\begin{array}{l}\text { Hauling } \\
\text { Empty }\end{array}$ \\
\hline & & $\begin{array}{c}\text { Charging } \\
\text { Time }\end{array}$ & & $\begin{array}{c}\text { Dumping } \\
\text { Time }\end{array}$ & $\begin{array}{l}\text { Hauling } \\
\text { Empty }\end{array}$ \\
\hline & $\begin{array}{l}\text { Duration } \\
\text { Time }\end{array}$ & $\begin{array}{c}9.48 \\
\text { minutes / } \\
\text { truck }\end{array}$ & $\begin{array}{c}18.56 \\
\text { minutes / } \\
\text { truck }\end{array}$ & $\begin{array}{c}2 \\
\text { minutes / } \\
\text { truck }\end{array}$ & $\begin{array}{c}17.31 \\
\text { minutes } \\
/ \text { truck }\end{array}$ \\
\hline & $\begin{array}{c}\text { Probability } \\
\text { of Arrival }\end{array}$ & $\begin{array}{c}7 \text { trucks / } \\
\text { hour }\end{array}$ & $\begin{array}{c}4 \text { trucks / } \\
\text { hour }\end{array}$ & $\begin{array}{c}30 \text { trucks / } \\
\text { hour }\end{array}$ & $\begin{array}{c}4 \text { trucks } \\
/ \text { hour }\end{array}$ \\
\hline \multirow{4}{*}{$\begin{array}{c}\text { Fleet } \\
\text { Kenanga }\end{array}$} & \multirow{2}{*}{$\begin{array}{l}\text { Activity } \\
\text { Details }\end{array}$} & $\begin{array}{c}\text { Time of } \\
\text { Placement }\end{array}$ & \multirow{2}{*}{ Hauling } & $\begin{array}{c}\text { Time of } \\
\text { Placement }\end{array}$ & \multirow{2}{*}{$\begin{array}{l}\text { Hauling } \\
\text { Empty }\end{array}$} \\
\hline & & $\begin{array}{c}\text { Charging } \\
\text { Time }\end{array}$ & & $\begin{array}{c}\text { Dumping } \\
\text { Time }\end{array}$ & \\
\hline & $\begin{array}{l}\text { Duration } \\
\text { Time }\end{array}$ & $\begin{array}{c}10.18 \\
\text { minutes / } \\
\text { truck }\end{array}$ & $\begin{array}{c}18.53 \\
\text { minutes / } \\
\text { truck }\end{array}$ & $\begin{array}{c}1.92 \\
\text { minutes / } \\
\text { truck }\end{array}$ & $\begin{array}{c}17 \\
\text { minutes } \\
/ \text { truck }\end{array}$ \\
\hline & \begin{tabular}{|c} 
Probability \\
of Arrival
\end{tabular} & $\begin{array}{c}6 \text { trucks / } \\
\text { hour }\end{array}$ & $\begin{array}{c}4 \text { trucks / } \\
\text { hour }\end{array}$ & $\begin{array}{c}32 \text { trucks / } \\
\text { hour }\end{array}$ & $\begin{array}{c}4 \text { trucks } \\
/ \text { hour }\end{array}$ \\
\hline
\end{tabular}

\subsection{Probability of Queue State}

Based on the actual conditions in the field, and following the concept of queuing theory, the calculation of the probability of queuing conditions uses the formula "Many Conditions". The number of transportation means is denoted by $(\mathrm{N})$, and the number of queuing stages is symbolized by (M) so that the number of queuing conditions is 165 conditions in the Anggrek pits and 35 conditions in the Dahlia and Kenanga pits (Table 4).

Table 4. Number of Probability of Conditions

\begin{tabular}{|c|c|c|c|c|}
\hline Fleet & \multicolumn{2}{|c|}{ Known } & Equation & $\begin{array}{l}\text { Number of } \\
\text { Probability }\end{array}$ \\
\hline \multirow{2}{*}{$\begin{array}{c}\text { Fleet } \\
\text { Anggrek }\end{array}$} & M & $\begin{array}{c}4 \\
\text { stage }\end{array}$ & \multirow{2}{*}{$\frac{(N+M-1) M}{(M-1) M(N) !}$} & \multirow{2}{*}{165} \\
\hline & $\mathrm{N}$ & 8 units & & \\
\hline \multirow{2}{*}{$\begin{array}{c}\text { Fleet } \\
\text { Dahlia }\end{array}$} & M & $\begin{array}{c}4 \\
\text { stage }\end{array}$ & \multirow{2}{*}{$\frac{(N+M-1) !}{(M-1) !(N) !}$} & \multirow{2}{*}{35} \\
\hline & $\mathrm{N}$ & 4 units & & \\
\hline \multirow{2}{*}{$\begin{array}{c}\text { Fleet } \\
\text { Kenang } \\
\mathrm{a}\end{array}$} & M & $\begin{array}{c}4 \\
\text { stage }\end{array}$ & \multirow{2}{*}{$\frac{(\mathrm{N}+\mathrm{M}-1) !}{(\mathrm{M}-1) \|(\mathrm{N}) !}$} & \multirow{2}{*}{35} \\
\hline & $\mathrm{N}$ & 4 units & & \\
\hline
\end{tabular}

\subsection{The Number of Haulers Queuing at The Loading Point (Lq 1) and ROM Kananai (Lq 3)}

The number of haulers queued at the loading point (Lq1) provided the value of $n 1>1$ on each fleet. In addition to the loading point, there was also a queue in stage 3, namely dumping at the Kananai ROM. The number of haulers queuing when dumping at Kananai ROM with a value of n3> 1 (Lq3). Each hauler has different waiting times, depending on the order of the queue. Wq1 symbolizes the waiting time. To get the value of $\mathrm{Wq} 1$, then calculate the excavator's busyness level ( $\eta 1$ ) first. The ZX-350H backhoe excavator hull number 2063 has a busyness rate of $97.42 \%$ with a maximum service of 7 trucks/hour, the PC-300 backhoe excavator hull number 2057 has a busyness rate of $68.70 \%$, and the $\mathrm{ZX}-250 \mathrm{H}$ backhoe excavator hull number 2064 has a busyness rate of $71.84 \%$ with a maximum service of 5 trucks/hour. For more details, the number of queues and queuing times can be seen in Table 5 .

Table 5. Number of Queues and Queue Time

\begin{tabular}{|c|c|c|c|c|}
\hline \multirow[b]{2}{*}{ Fleet } & Phase I & $\begin{array}{l}\text { Phase } \\
\text { II }\end{array}$ & Phase III & Phase IV \\
\hline & $\begin{array}{c}\text { Time of } \\
\text { Placement } \\
\text { Charging Time }\end{array}$ & Hauling & $\begin{array}{c}\text { Time of } \\
\text { Placement } \\
\text { Dumping Time }\end{array}$ & $\begin{array}{l}\text { Hauling } \\
\text { Empty }\end{array}$ \\
\hline $\begin{array}{c}\text { Fleet } \\
\text { Anggrek }\end{array}$ & $\begin{array}{c}3 \text { Trucks } \\
\text { Queuing for } 6.8 \\
\text { minutes }\end{array}$ & $\begin{array}{c}\text { No } \\
\text { Queue }\end{array}$ & $\begin{array}{c}1 \text { Truck } \\
\text { Queuing for } 2.1 \\
\text { minutes }\end{array}$ & No Queue \\
\hline $\begin{array}{l}\text { Fleet } \\
\text { Dahlia }\end{array}$ & $\begin{array}{c}1 \text { Truck } \\
\text { Queuing for } 7.5 \\
\text { minutes }\end{array}$ & $\begin{array}{c}\text { No } \\
\text { Queue }\end{array}$ & $\begin{array}{c}1 \text { Truck } \\
\text { Queuing for } \\
0.25 \text { minutes }\end{array}$ & No Queue \\
\hline $\begin{array}{c}\text { Fleet } \\
\text { Kenanga }\end{array}$ & $\begin{array}{c}1 \text { Truck } \\
\text { Queuing for } 8.7 \\
\text { minutes }\end{array}$ & $\begin{array}{c}\text { No } \\
\text { Queue }\end{array}$ & $\begin{array}{c}1 \text { Truck } \\
\text { Queuing for } \\
0.22 \text { minutes }\end{array}$ & No Queue \\
\hline
\end{tabular}



Figure 2: Actual Fleet Management

The actual condition of using tools in Blok Kananai is 1 loader unit with 8 units of haulers on the Anggrek pit, 1 loader unit with 4 units of haulers on the Dahlia and Kenanga pits. In the actual fleet condition (Figure 2), it is known that there is a queue of 3 units of dump trucks on the front of Anggrek pit mining. Simultaneously, the Dahlia and Kenanga fleets occur depending on the carrier so that the production target is not reached. Therefore, the tool needs analysis using queue theory and estimated the needs of 
Fahrul Indrajaya et al., International Journal of Emerging Trends in Engineering Research, 8(10), October 2020, 7099 - 7104

haulers by considering competitiveness. Here is an estimate of using the number of tools (Table 6) of Blok Kananai based on the match factor equation.

Table 6. Estimated Use of Kananai Block Tools

\begin{tabular}{|c|c|c|c|c|c|c|c|}
\hline \multirow{2}{*}{ No. } & \multicolumn{2}{|c|}{ Anggrek } & \multirow{2}{*}{$\begin{array}{c}\text { MF } \\
\text { Value }\end{array}$} & \multirow{2}{*}{$\begin{array}{c}\text { Wait } \\
\text { time } \\
\text { Loader } \\
\text { (Minute) } \\
\end{array}$} & \multirow{2}{*}{$\begin{array}{c}\text { Wait for } \\
\text { time } \\
\text { Haulers } \\
\text { (Minute) }\end{array}$} & \multirow{2}{*}{$\begin{array}{l}\text { Production/ } \\
\text { Month }\end{array}$} & \multirow{2}{*}{ Targets } \\
\hline & \begin{tabular}{|l|} 
Loader \\
\end{tabular} & Haulers & & & & & \\
\hline 1 & 1 & 1 & 0.16 & 38 & - & $8,402.23$ & $\begin{array}{c}\text { Not } \\
\text { Achieved }\end{array}$ \\
\hline 2 & 1 & 2 & 0.33 & 15 & - & $16,804.46$ & $\begin{array}{c}\text { Not } \\
\text { Achieved }\end{array}$ \\
\hline 3 & 1 & 3 & 0.50 & 7 & - & $25,206.68$ & $\begin{array}{c}\text { Not } \\
\text { Achieved }\end{array}$ \\
\hline 4 & 1 & 4 & 0.67 & 3.7 & - & $33,611.99$ & $\begin{array}{c}\text { Not } \\
\text { Achieved }\end{array}$ \\
\hline 5 & 1 & 5 & 0.84 & 1.4 & - & $42,014.22$ & $\begin{array}{c}\text { Not } \\
\text { Achieved }\end{array}$ \\
\hline 6 & 1 & 6 & 1.01 & - & $\begin{array}{c}5.4 \\
\text { seconds }\end{array}$ & $50,416.45$ & Achieved \\
\hline 7 & 1 & 7 & 1.18 & - & 1.1 & $58,821.76$ & Achieved \\
\hline 8 & 1 & 8 & 1.34 & - & 2.0 & $67,223.99$ & Achieved \\
\hline \multirow{2}{*}{ No. } & \multicolumn{2}{|c|}{ Dahlia } & \multirow{2}{*}{$\begin{array}{c}\text { MF } \\
\text { Value }\end{array}$} & \multirow{2}{*}{$\begin{array}{c}\text { Wait } \\
\text { time } \\
\text { Loader } \\
\text { (Minute) } \\
\end{array}$} & \multirow{2}{*}{$\begin{array}{c}\text { Wait for } \\
\text { time } \\
\text { Haulers } \\
\text { (Minute) }\end{array}$} & \multirow{2}{*}{$\begin{array}{l}\text { Production/ } \\
\text { Month }\end{array}$} & \multirow{2}{*}{ Targets } \\
\hline & Loader & Haulers & & & & & \\
\hline 1 & 1 & 1 & 0.19 & 37 & - & $6,240.8$ & $\begin{array}{c}\text { Not } \\
\text { Achieved }\end{array}$ \\
\hline 2 & 1 & 2 & 0.39 & 14.2 & - & $12,969.7$ & $\begin{array}{c}\text { Not } \\
\text { Achieved }\end{array}$ \\
\hline 3 & 1 & 3 & 0.59 & 6.4 & - & $19,454.6$ & $\begin{array}{c}\text { Not } \\
\text { Achieved }\end{array}$ \\
\hline 4 & 1 & 4 & 0.79 & 2 & - & $25,939.4$ & $\begin{array}{c}\text { Not } \\
\text { Achieved }\end{array}$ \\
\hline 5 & 1 & 5 & 0.98 & \begin{tabular}{|c|}
6 \\
seconds \\
\end{tabular} & - & $32,424.3$ & Achieved \\
\hline 6 & 1 & 6 & 1.18 & - & 1.4 & $38,909.2$ & Achieved \\
\hline \multirow{2}{*}{ No. } & \multicolumn{2}{|c|}{ Kenanga } & \multirow{2}{*}{$\begin{array}{c}\text { MF } \\
\text { Value }\end{array}$} & \multirow{2}{*}{$\begin{array}{c}\text { Wait } \\
\text { time } \\
\text { Loader } \\
\text { (Minute) }\end{array}$} & \multirow{2}{*}{$\begin{array}{c}\begin{array}{c}\text { Wait for } \\
\text { time } \\
\text { Haulers } \\
\text { (Minute) }\end{array} \\
\end{array}$} & \multirow{2}{*}{$\begin{array}{l}\text { Production/ } \\
\text { Month }\end{array}$} & \multirow{2}{*}{ Targets } \\
\hline & Loader & Haulers & & & & & \\
\hline 1 & 1 & 1 & 0.2 & 37.70 & - & $9,202.4$ & $\begin{array}{c}\text { Not } \\
\text { Achieved }\end{array}$ \\
\hline 2 & 1 & 2 & 0.41 & 13.88 & - & $18,408.4$ & $\begin{array}{c}\text { Not } \\
\text { Achieved }\end{array}$ \\
\hline 3 & 1 & 3 & 0.62 & 5.93 & - & $27,615.1$ & $\begin{array}{c}\text { Not } \\
\text { Achieved }\end{array}$ \\
\hline 4 & 1 & 4 & 0.83 & 1.96 & - & 5 & $\begin{array}{c}\text { Not } \\
\text { Achieved }\end{array}$ \\
\hline 5 & 1 & 5 & 1.04 & - & $\begin{array}{c}24 \\
\text { seconds }\end{array}$ & $46,027.8$ & Achieved \\
\hline 6 & 1 & 6 & 1.25 & - & 2 & $55,234.2$ & Achieved \\
\hline
\end{tabular}

Based on the queue theory and the estimated number of haulers in the table above, it is recommended to use the recommended tools to reduce queues and reach the monthly production target. A real-time picture of the Kananai Block fleet management simulation can be seen in Figure 3, Figure 4, and Figure 5.

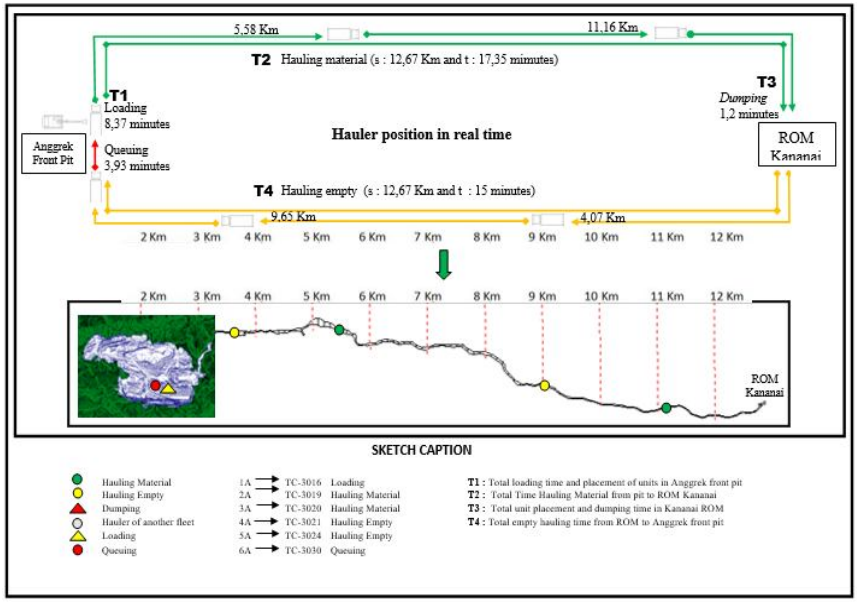

Figure 3: Management simulation of the anggrek fleet

In Figure 3, it is shown that the Anggrek fleet only uses 6 transport units. This simulation is carried out to reduce the possibility of queues while maximizing the fleet at Anggrek pit. The allocation of 2 haulers from the Anggrek fleet is aimed at the Dahlia fleet and the Kenanga fleet, namely the TC-3033 and TC 3034. This allocation has a good impact on the level of suitability of equipment in the Anggrek pit to 1.01 with a production of 50,416.45 tons of coal and achieving the production target. Dahlia fleet management simulation is carried out with the allocation of 1 unit haulers from the Anggrek fleet. The number of haulers working in the Dahlia fleet is changed to 5 units. Allocation efforts can increase production and reach the monthly plan target; namely, Dahlia pit production to $32,424.3$ tons with a harmony value of 0.98 . Based on the queue (Figure 4), the queue only occurs when TC-3048 is dumping in the ROM.



Figure 4: Management simulation of the dahlia fleet 


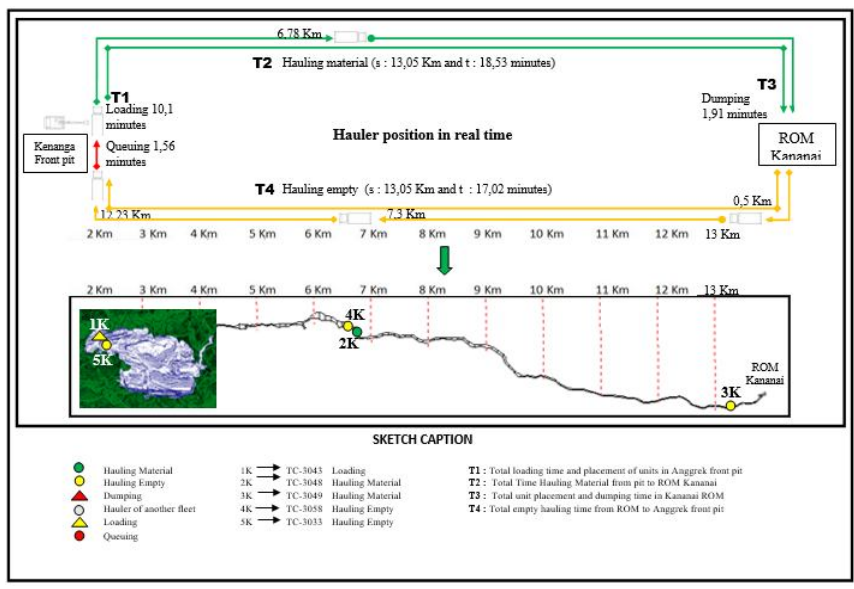

Figure 5: Kenanga fleet management simulation

Based on Figure 5, it can be known that there are 1 unit haulers (TC-3034) queuing at the front loading pit Kenanga. Based on the queue theory and estimated level of harmony in the haulers, fleet Kenanga uses 5 units of haulers. Efforts to add this unit increased Kenanga fleet production to 46,027.8 tons and the value of harmony 1.04. Fleet management simulation design The Kananai Block in each pit is 1:6 (fleet Anggrek), 1:5 (fleet Dahlia), and 1:5 (fleet Kenanga). Result in match factor analysis $1.01,0.98$, and 1.04 with the capability production of each Simulation 50,416.45 tons, $32,424.3$ tons, and $46,027.8$ tons.

\section{CONCLUSIONS}

The design of the Blok Kananai block fleet management simulation begins with analyzing the number of transportation needs based on queuing theory and an estimate of the suitability factor. Based on the calculation results, 2 hauler units were allocated from the Anggrek fleet to the Dahlia and Kenanga fleets, 1 unit each to minimize queues at the Anggrek pit while maximizing the performance of the Dahlia and Kenanga fleets. The use of tools is 1 loader unit with 6 hauler units run at the Anggrek pit, 1 loader unit with 5 hauler units run at the Dahlia pit, and 1 loader unit with 5 hauler units run at the Kenanga pit. Based on the suitability factors, which are 1.01, 0.98, and 1.04 , each simulation achieves the corresponding monthly plan target with high production capabilities.

\section{ACKNOWLEDGEMENTS}

The author would like to express his deepest gratitude to the Mining Engineering Study Program, Faculty of Engineering, Universitas Palangka Raya, for providing research permits in the Kananai Block, East Barito Regency, Central Kalimantan Province with independent funding sources.

\section{REFERENCES}

[1] C. N. Burt and L. Caccetta, Erratum to: Equipment Selection for Mining: With Case Studies. 2018.

[2] W. Zeng, E. Baafi, and D. Walker, "A simulation model to study bunching effect of a truck-shovel system," Int. J. Mining, Reclam. Environ., vol. 33, no. 2, pp. 102-117, 2019, doi: 10.1080/17480930. 2017.1348284.

[3] D. Sembakutti, M. Kumral, and A. P. Sasmito, "Analysing equipment allocation through queuing theory and Monte-Carlo simulations in surface mining operations," Int. J. Min. Miner. Eng., vol. 8, no. 1, pp. 56-69, 2017, doi: 10.1504/ IJMME.2017.082693.

[4] A. Moradi Afrapoli and H. Askari-Nasab, "Mining fleet management systems: a review of models and algorithms," Int. J. Mining, Reclam. Environ., vol. 33, no. 1, pp. 42-60, 2017, doi: 10.1080/ 17480930.2017.1336607.

[5] A. Moradi Afrapoli, M. Tabesh, and H. AskariNasab, "A multiple objective transportation problem approach to dynamic truck dispatching in surface mines," Eur. J. Oper. Res., vol. 276, no. 1, pp. 331-342, 2019, doi: 10.1016/j.ejor.2019.01. 008 .

[6] O. O. Gorshkova, "Modernization of Transport Management System upon Conveyance of Bulk Goods," Int. J. Emerg. Trends Eng. Res., vol. 8, no. 3, pp. 659-662, 2020, [Online]. Available: https://doi.org/10.30534/ijeter/2020/08832020.

[7] J. E. Cheng, "Match Factor Determination of Excavator-Truck Combination in Surface Mining: Case Study of Merit Pila Coalfield, Sarawak," Geol. Behav., vol. 3, no. 1, pp. 28-29, 2019, doi: 10.26480/gbr.01.2019.28.29.

[8] P. Chaowasakoo, H. Seppälä, H. Koivo, and Q. Zhou, "Improving fleet management in mines: The benefit of heterogeneous match factor," Eur. J. Oper. Res., vol. 261, no. 3, pp. 1052-1065, 2017, doi: 10.1016/j.ejor.2017.02.039.

[9] C. Both and R. Dimitrakopoulos, "Joint stochastic short-term production scheduling and fleet management optimization for mining complexes," Optim. Eng., no. 0123456789, 2020, doi: 10.1007/s11081-020-09495-x.

[10] A. Jaoua, D. Riopel, and M. Gamache, "A simulation framework for real-time fleet management in internal transport systems," Simul. Model. Pract. Theory, vol. 21, no. 1, pp. 7890, 2012, doi: 10.1016/j.simpat.2011.10.003.

[11] A. S. Hashemi and J. Sattarvand, "Simulation based investigation of different fleet management paradigms in open pit mines-a case study of Sungun copper mine," Arch. Min. Sci., vol. 60, no. 1, pp. 195-208, 2015, doi: 10.1515/amsc-2015-0013.

[12] A. Dabbagh and R. Bagherpour, "Development of a Match Factor and Comparison of Its Applicability with Ant-Colony Algorithm in a Heterogeneous Transportation Fleet in an OpenPit Mine," J. Min. Sci., vol. 55, no. 1, pp. 45-56, 2019, doi: 10.1134/S1062739119015287.

[13] F. Monnerat, J. Dias, and M. J. Alves, "Fleet management: A vehicle and driver assignment 
model," Eur. J. Oper. Res., vol. 278, no. 1, pp. 6475, 2019, doi: 10.1016/j.ejor.2019.03.021.

[14] R. Pascual, M. Román, M. López-Campos, M. Hitch, and E. Rodovalho, "Reducing mining footprint by matching haul fleet demand and route-oriented tire types," J. Clean. Prod., vol. 227, pp. 645-651, 2019, doi: 10.1016/j.jclepro.2019. 04.069 .

[15] E. Topal and S. Ramazan, "Mining truck scheduling with stochastic maintenance cost," $J$. Coal Sci. Eng., vol. 18, no. 3, pp. 313-319, 2012, doi: 10.1007/s12404-012-0316-4.

[16] M. G. Raj, H. Vardhan, and Y. V. Rao, "Production optimisation using simulation models in mines: A critical review," Int. J. Oper. Res., vol. 6, no. 3, pp. 330-359, 2009, doi: 10.1504/IJOR.2009.026937.

[17] V. Fedorenko, I. Fedorenko, A. Sukmanov, V. Samoylenko, D. Shlaev, and I. Atanov, "Modeling of data acquisition systems using the queueing theory," AEU - Int. J. Electron. Commun., vol. 74, pp. 83-87, 2017, doi: 10.1016/j.aeue.2017.01.024.

[18] Sumadi, Jumintono, and F. Ardiani, "Supply chain brown sugar agroindustry in Banyuwangi district: Analysis study with a dynamic system approach," Int. J. Supply Chain Manag., vol. 9, no. 1, pp. 626-632, 2020.

[19] D. M. Bajany, L. Zhang, and X. Xia, "An Optimization Approach for Shovel Allocation to Minimize Fuel Consumption in Open-pit Mines: Case of Heterogeneous Fleet of Shovels," IFACPapersOnLine, vol. 52, no. 14, pp. 207-212, 2019, doi: 10.1016/j.ifacol.2019.09.196.

[20] C. N. Burt and L. Caccetta, "Match factor for heterogeneous truck and loader fleets," Int. J. Mining, Reclam. Environ., vol. 21, no. 4, pp. 262270, 2007, doi: 10.1080/17480930701388606.

[21] B. Ozdemir and M. Kumral, "Stochastic Assessment of the Material Haulage Efficiency in the Earthmoving Industry," J. Constr. Eng. Manag., vol. 143, no. 8, pp. 1-9, 2017, doi: 10.1061/(ASCE)CO.1943-7862.0001336.

[22] M. Fisonga and V. Mutambo, "Optimization of the fleet per shovel productivity in surface mining: Case study of Chilanga Cement, Lusaka Zambia," Cogent Eng., vol. 4, no. 1, pp. 1-16, 2017, doi: 10.1080/23311916.2017.1386852.

[23] M. E. V. Matamoros and R. Dimitrakopoulos, "Stochastic short-term mine production schedule accounting for fleet allocation, operational considerations and blending restrictions," Eur. $J$. Oper. Res., vol. 255, no. 3, pp. 911-921, 2016, doi: 10.1016/j.ejor.2016.05.050.

[24] R. A. Memon, J. P. Li, and J. Ahmed, "Simulation model for blockchain systems using queuing theory," Electron., vol. 8, no. 2, pp. 1-19, 2019, doi: 10.3390/electronics8020234.
[25] Y. Feng and Z. Dong, "Optimal energy management with balanced fuel economy and battery life for large hybrid electric mining truck," J. Power Sources, vol. 454, no. November 2019, pp. 1-12, 2020, doi: 10.1016/j.jpowsour.2020. 227948.

[26] Y. Hidayat, T. Purwandari, A. Bachrudin, A. A. Nurjannah, A. Santoso, and Sukono, "Preventive maintenance supply chain management optimal scheduling on VMACL machines by implementing simulation annealing algorithms," Int. J. Supply Chain Manag., vol. 9, no. 3, pp. 5257, 2020. 